\title{
UWARUNKOWANIA SPOŁECZNO-EKONOMICZNE OSADNICTWA UCHODŹCÓW BUŁGARSKICH W LATACH DWUDZIESTYCH XX WIEKU
}

\author{
JĘDRZEJ PASZKIEWICZ
}

\begin{abstract}
Socio-economic conditions of refugees'settlement in Bulgaria in the 1920s.
The influx of immigrants into Bulgaria during the first two decades of 20th Century was a result of the two lost armed conflicts and border shifts between 1913 and 1918. These changes in turn resulted in the disruption of the socio-political and economic situation within the country. The government was unable to efficiently overcome the consequences of high immigration, which aggravated the already present social and economic difficulties and threatened the internal stability of the state. On the other hand, in spite of the grave political and economic crisis, certain measures were undertaken to counter the negative tendencies, with the state support for the agricultural settlement. The partial success of the above was possible due to the agriculture reform introduced in 1924 and financial credits from abroad $(1926,1928)$. The outcome was sufficient for the Bulgarian government to deem the settlement action a success, an enhancement of the country's internal stability and appeasement of the general public. Nevertheless, a number of pressing issues remained, resulting mostly from a lack of systemic support of the immigrants and their families. The refugee integration process was hindered by the lack of a secure economic foundation and the differences among the particular social groups.
\end{abstract}

STRESZCZENIE. Napływ imigrantów do Bułgarii, obserwowany w dwóch pierwszych dziesięcioleciach XX wieku, był spowodowany przez klęski wojenne i zmiany graniczne w okresie 1913-1918. Przyczynił się on do zachwiania relacji społeczno-politycznych i ekonomicznych w państwie. Władze nie radziły sobie z następstwami imigracji, która spotęgowała dotychczasowe problemy społeczno-gospodarcze kraju i zagrażała jego stabilności wewnętrznej. Z drugiej strony, mimo głębokiego kryzysu polityczno-ekonomicznego państwa, w miarę możliwości starano się przeciwdziałać niekorzystnym tendencjom, głównie poprzez rozwijanie osadnictwa rolniczego. Częściowe powodzenie tych zabiegów było możliwe dzięki przeprowadzeniu reformy rolnej (1924) i wsparciu kredytowemu z zagranicy $(1926,1928)$. W rezultacie, władze bułgarskie uznały akcję osadniczą za sukces, który przyczynił się wewnętrznej stabilizacji państwa i uspokojenia nastrojów społecznych. $\mathrm{Z}$ drugiej strony, do rozwiązania zostało wiele nabrzmiałych problemów, które wynikały z braku systemowego wsparcia dla przybyszów i ich rodzin. Proces integracji uchodźców ze strukturami państwa opóźniał się z uwagi na brak stabilnych podstaw ekonomicznych i istniejące odrębności w ramach poszczególnych grup.

Autor: Jędrzej Paszkiewicz, Uniwersytet im. Adama Mickiewicza w Poznaniu, Instytut Historii, ul. Umultowska 89d, 61-614 Poznań, Polska, e-mail: paszje@wp.pl

Keywords: Bulgaria, refugees, immigrants, settlement

Słowa kluczowe: Bułgaria, uchodźcy, imigranci, osadnictwo

Balcanica Posnaniensia. Acta et studia, XXIV, Poznań 2017, Wydawnictwo Instytutu Historii UAM, pp. 61-81, ISBN 978-83-65663-50-4, ISSN 0239-4278. Polish text with summaries in English and Polish.

doi.org/10.14746/bp.2017.24.5 
Spośród blisko 10 milionów ludzi, którzy w ciągu trzech pierwszych dekad XX wieku w Europie stali się imigrantami lub uchodźcami, blisko 250 tysięcy stanowiła ludność bułgarskojęzyczna ${ }^{1}$. Największe migracje do Bułgarii nastąpiły w dwóch okresach: w trakcie wojen bałkańskich (1912-1913) i po pierwszej wojnie światowej. Dla państwa, które jeszcze w 1910 roku liczyło nieco ponad 4 miliony mieszkańców, napływ tak dużej liczby nowej ludności stanowił olbrzymie obciążenie, a także wyzwanie ze społeczno-politycznego oraz ekonomicznego punktu widzenia ${ }^{2}$.

W literaturze naukowej dają o sobie znać problemy z oceną liczebności imigrantów, którzy w omawianym okresie przybyli do Bułgarii, głównie z państw sąsiednich. Szacunkowo, w latach 1912-1915 na terytorium bułgarskim odnotowano ponad 120 tysięcy przybyszów, przeważnie z ziem trackich i macedońskich oraz Dobrudży. Ówczesne migracje należy uznać za następstwo zmian granicznych, które nastąpiły po bułgarskiej klęsce w drugiej wojnie bałkańskiej (1913). Na około 180 tysięcy uchodźców szacuje się tzw. drugą falę imigracji, która nastąpiła w okresie 19151924. W tym przypadku za początkową cezurę przyjmuje się przystąpienie Bułgarii do I wojny światowej po stronie państw centralnych. Datę końcową wyznacza finał międzyrządowych akcji migracyjnych, które władze bułgarskie prowadziły z Grecją po zakończeniu działań wojennych ${ }^{3}$. Obok kolejnych imigrantów z ziem trackich (pod panowaniem Turcji i Grecji), macedońskich (pod panowaniem Grecji i państwa jugosłowiańskiego) i rumuńskiej Dobrudży, do Bułgarii napłynęli w większej ilości uchodźcy z obszarów znajdujących się na pograniczu bułgarsko-serbskim, przy-

\footnotetext{
${ }^{1} \mathrm{~W}$ bułgarskiej literaturze naukowej, a także w dokumentacji państwowej, termin ,uchodźca” dotyczy ludności, która przybyła do Bułgarii w następstwie trzech konfliktów wojennych, pierwszej i drugiej wojny bałkańskiej (1912-1913) oraz I wojny światowej (1914-1918). Zgodnie z bułgarskimi przepisami, o status uchodźcy mogli ubiegać się tylko ci, którzy przybyli między październikiem 1912 roku a grudniem 1926 roku. Określenie to odnosi się do około 253 tysięcy osób, czyli prawie 56 tysięcy rodzin; por. V. Mintchev, External migration and external migration policies in Bulgaria, „South-East Europe Review for Labour and Social Affairs" 1999, t. 2, nr 3, s. 124-125.

2 Jak wynikało z pierwszego spisu ludności w Bułgarii z 1910 roku, liczba ludności tego państwa wynosiła 4337 513. W spisie z 1920 roku odnotowano 4846971 osób, a w 1926 roku i w 1934 roku odpowiednio 5528741 i 6077 939; Царство България. Главна Дирекция на Статиската, Преброяване на населението. 1934, София 1935, s. VII.

${ }^{3}$ W 1926 roku szacowano, że najwięcej uchodźców, blisko 48\% przybyło do Bułgarii z Grecji, głównie z greckiej części Tracji i Macedonii (Macedonia egejska). Na około 25\% szacowano przybyszów z tureckiej Tracji wschodniej, a na 12,5 uchodźców z obszaru Królestwa Serbów, Chorwatów i Słoweńców, głównie z serbskiej części Macedonii (Macedonia wardarska) i terenów nadgranicznych z Bułgarią. 11\% imigrantów miało pochodzić z południowej Dobrudży w Rumunii a 3\% przybyć do

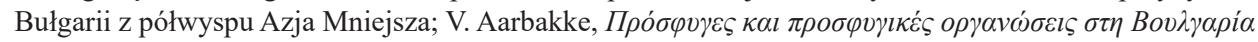

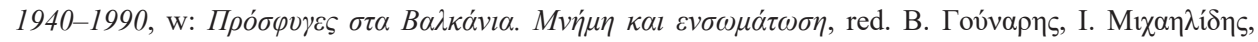

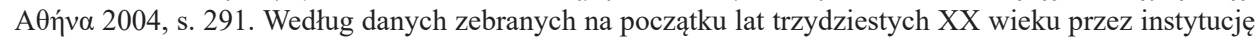
rządową, Główną Dyrekcję do Spraw Osadnictwa Uchodźców, najwięcej przybyszów wskazywało, że urodziło się w Macedonii egejskiej (31\%), a następnie w Tracji pod panowaniem tureckim (25\%), Tracji pod panowaniem Grecji (17\%), Dobrudży (11\%), Macedonii wardarskiej (8\%), na terenach przygranicznych z Serbią (4,5\%) i na Półwyspie Azja Mniejsza (3\%). W powyższym zestawieniu uwzględniono łącznie ponad 253 tysiące osób; K. Хитилов, Селскостопанското настаняване на бежанците 19271932 г., София 1932.
} 
łączonych do Królestwa SHS: z rejonu Caribrodu, Bosilegradu, Trynu (buł. Трън) i Kuły (buł. Кула). Dodać należy, że w omawianym okresie Bułgaria stała się także azylem dla około 40 tysięcy Rosjan i 20 tysięcy Ormian, którzy opuścili Rosję i Turcję w związku z tamtejszymi konfliktami zbrojnymi (1917-1922) ${ }^{4}$. Według danych opublikowanych w 1926 przez rządowy departament do spraw uchodźców, działający przy bułgarskim Ministerstwie Spraw Zagranicznych, liczba imigrantów, którzy przybyli do Bułgarii w latach 1913-1925 i zostali zarejestrowani przez władze, wynosiła około 52 tysięcy rodzin, co stanowiło ponad 221 tysięcy osób. Informacje te zebrano na podstawie formularzy, które uchodźcy wypełniali w punktach przygranicznych. Na tej podstawie władze uzyskały pewną wiedzę na temat miejsca pochodzenia czy statusu zawodowego przybyszów. I tak, w dokumentacji na rok 1926 figurowało 83155 mężczyzn, 67716 kobiet, 70320 dzieci. Dominowali wśród nich pracownicy fizyczni, wcześniej związani z drobną gospodarką rolną oraz wiejscy rzemieślnicy ${ }^{5}$. Niemożliwa do oszacowania jest liczba imigrantów, którzy z różnych powodów nie poddali się wówczas procedurze rejestracyjnej. Obserwowane w latach dwudziestych zjawisko unikania rejestracji dotyczyło zwłaszcza rodzin przybywających z Dobrudży i tureckiej części Tracji. Najczęściej motywowano je brakiem zaufania dla działań administracji, która zwykle nie pozostawiała uchodźcom wyboru co do miejsca zamieszkania. Część imigrantów próbowała odnaleźć się w nowym kraju bez korzystania z pośrednictwa urzędników. Większość uchodźców w Bułgarii kierowała się jednak do punktów rejestracyjnych, oczekując od państwa pomocy finansowej. Zwykle przybywający nie posiadali wystarczających funduszy, aby przetrwać nawet przez pierwsze miesiące pobytu, czy też podjąć dochodową aktywność zawodową. W 1926 roku szacowano, że aktywnej pomocy finansowej i materiałowej ze strony państwa wymagało blisko 41 tysięcy rodzin, najczęściej osiedlonych na wsí .

Sytuacja ta dotyczyła również ponad 66 tysięcy osób, które przybyły do Bułgarii z Grecji w ramach dwustronnej konwencji o tzw. dobrowolnej migracji ludności, dołączonej do paktu pokojowego z Neuilly z listopada 1919 roku. Umowa ta przewidywała wypłatę zadośćuczynienia finansowego za pozostawione mienie ${ }^{7}$ Początkowo

${ }^{4}$ International Labour Office [dalej: ILO], Refugees and labour conditions in Bulgaria, ,Studies and reports" 1926 , ser. B, nr 15 , s. 2-5.

5 ILO, op. cit., s. 18.

${ }^{6}$ Г. Димитров, Настаняване и оземляване на българските бежанци: 1919-1939, Благоевград 1985, s. 165.

${ }^{7}$ Największe fale migracji z Grecji odnotowano w pierwszej połowie lat dwudziestych XX wieku w związku z naciskami władz greckich które zmierzały do usunięcia ludności pochodzenia słowiańskiego, zamieszkującej Macedonię oraz Trację. I tak, w latach 1912-1920 Bułgarzy emigrowali głównie z Macedonii egejskiej, ich liczbę szacuje się na około 105 tysięcy osób. W 1920 roku liczbę ludności bułgarskiej, która pozostała w greckiej Macedonii szacowano na około 17 tysięcy. W latach 1920-1924 wśród przybyszów z Grecji dominowali uchodźcy z Tracji. Liczba Bułgarów zamieszkujących ten region w omawianym okresie zmniejszyła się z 35 tysięcy do około 23 tysięcy osób. Spośród najważniejszych wydarzeń, które wywołały kolejne fale migracyjne między Grecją a Bułgarią po zakończeniu I wojny światowej, należy wymienić fiasko planów stworzenia autonomicznej Tracji (1919), wkroczenie greckiej administracji i wojska do zachodniej części regionu (1920), a następnie inkorporację tego regionu przez 
obejmowała ona tylko ludność ze wschodniej części Macedonii, w 1923 roku rozciągnięto ją na bułgarskojęzycznych mieszkańców greckiej części Tracji, którzy nie zdążyli jeszcze opuścić tego regionu. Zgodnie z postanowieniami konwencji, ludność ta otrzymała możliwość emigracji do tzw. kraju macierzystego, z gwarancją otrzymania rekompensaty finansowej za postawioną własność. Na obiecywany ekwiwalent miały się złożyć gotówka (10\%) i obligacje państwowe $(90 \%)^{8}$. Członkowie podkomisji międzynarodowej, powołanej celem zapewnienia realizacji tego przedsięwzięcia (Смесената гръияко-българска подкомисия за размяна) podkreślali, że nie miało ono charakteru obowiązkowego, tak jak to było w przypadku akcji wymiany ludności realizowanej w latach 1923-1925 między Grecją a Turcją ${ }^{9}$. Decyzja o wyjeździe należała do zainteresowanych osób a nie administracji. Emigranci musieli jednak zrzec się dotychczasowego obywatelstwa i zapewnić, że nie powrócą do swoich domostw. Zaznaczyć trzeba, że finansowe rozliczenia umowy migracyjnej budziły wieloletnie kontrowersje. W rezultacie, prace nad finansową wyceną nieruchomości, pozostawionych w Grecji przez bułgarskich emigrantów, a także spory o liczbę osób uprawnionych do otrzymania rekompensat trwały aż do końca 1931 roku $^{10}$.

W większości rodziny imigrantów, przybywające do Bułgarii, były osadzane na obszarach przylegających do granic z Grecją, Turcją i Królestwem SHS. Tam przyby-

Grecję w następstwie postanowień traktatu pokojowego z Lozanny (1923). Ludność słowiańska, w tym również i bułgarskiego pochodzenia, była w Grecji uznana za niepożądaną, bo zagrażającą bezpieczeństwu państwa. Władze uważały, że wspierała ona antygreckie bandy, operujące w trudno dostępnych górskich rejonach przygranicznych. Władzom greckim zależało na emigracji jak największej liczby Bułgarów ze względu na masowy napływ Greków z Azji Mniejszej i Tracji wschodniej w następstwie klęski w wojnie z Turcją; „League of Nations. Official journal” 1921, t. 1 (maj-kwiecień), s. 122; Ethnic minorities in the Balkan states 1860-1971, red. B. Destani, London 2003, t. 3, s. 245-247, 691-693.

${ }^{8}$ W 1929 roku szacowano, że postanowieniom konwencji o wzajemnej dobrowolnej emigracji (1919) podlegało blisko 90 tysięcy Bułgarów i 50 tysięcy Greków. Wedle szacunków, do końca 1923 roku Grecję opuściło około 45 tysięcy osób pochodzenia bułgarskiego, a Bułgarię niespełna 17 tysięcy Greków. Z kolei w latach 1923-1924 na emigrację z greckiej Macedonii i Tracji zdecydowało się około 80 tysięcy osób pochodzenia bułgarskiego. W tym samym okresie Bułgarię opuściło około 25 tysięcy Greków. Większość przesiedleńców nie zdołała uregulować spraw majątkowych przed udaniem się na

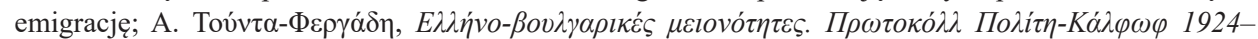

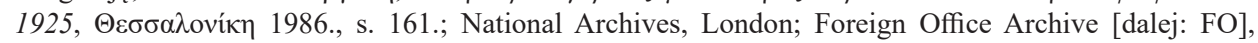
371/12864, Bulgaria. Annual report 1927, s. 28-29; idem, 371/14326; Bulgaria. Annual report 1929, s. 20.

${ }^{9}$ Ethnic minorities, t. 4, s. 228.

10 Spośród bułgarsko- i greckojęzycznych opracowań na temat dobrowolnej wymiany ludności między Bułgarią a Grecją: Г. Димитров, Малцинствено-бежанският въпрос в българо-гръцките отношения (1919-1939), Благоевград 1982; idem, Илюзии и действителност. Спорове за права и имоти на българите от Егейска Македония и Западна Тракия 1919-1931 г., Благоевград, 1996;

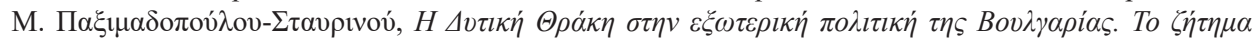

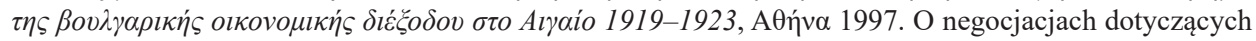
finansnowego rozliczenia konwencji bułgarsko-greckiej z 1919 roku: Д. Вачков, Отношенията на България с международните финансови среди, 1926-1931, w: История на външния държавен дълг на България 1878-1990 г., red. М. Иванов, Ц. Тодорова, Д. Вачков, ; София 2009, t. 2, 80-89. 
sze tworzyli stosunkowo zwarte grupy ludności ${ }^{11}$. Najliczniejsze skupiska Bułgarówimigrantów znalazły schronienie głównie w przygranicznych okręgach Burgas, Chaskowo i Kyrdżali. Imigranci z Grecji osiedlali się przeważnie w Petricz i Płowdiw, z kolei Bułgarzy z greckiej części Tracji licznie zasiedlili okręg Chaskowo. W okręgach Burgas i Szumen dominowali Bułgarzy migrujący z tureckiej części Tracji, która znajdowała się pod kontrolą Turcji. Do Burgas i wschodniej części Rodopów przybywali także imigranci z Azji Mniejszej. Bardziej rozproszone były wspólnoty, przybywające z terenu Królestwa SHS, które dość licznie osiedlały się wzdłuż południowozachodniej granicy ${ }^{12}$.

Zdaniem ekspertów Międzynarodowej Organizacji Pracy (MOP; ang. International Labour Organization - ILO), w połowie lat dwudziestych XX wieku, spośród około 52 tysięcy rodzin uchodźców, aż 75 \% utrzymywało się z rolnictwa. Dawało to liczbę około 39 tysięcy rodzin, którym należało zapewnić podstawy bytowe, najlepiej na wsi. Spośród tej liczby do połowy lat dwudziestych na ziemi gospodarowało zaledwie około 13500 rodzin, które otrzymały ją od państwa, bądź kupiły za własne oszczędności. W większości przypadków parcele uprawiane przez imigrantów były zbyt małe, aby rodziny mogły utrzymać się wyłącznie z pracy na roli. W ocenie MOP, ci, którzy po przybyciu do Bułgarii stosunkowo szybko nabyli ziemię i podjęli działalność rolniczą, najczęściej wymagali szybkiego wsparcia w postaci dodatkowej ziemi ornej, narzędzi, zwierząt pociągowych lub hodowlanych ${ }^{13}$.

Według poglądu członków Wysokiej Rady do Spraw Pracy i Bezpieczeństwa Społecznego, reprezentującej stronę bułgarską w MOP, złożonego z przedstawicieli różnych grup społecznych, w tym także przedsiębiorców i bankowców, gwałtowny napływ imigrantów zagrażał fundamentom ładu gospodarczego i społecznego w Bułgarii. Duża liczba przybyszów, najczęściej pozbawionych podstawowych środków do życia, nie mogła zostać wchłonięta przez miejscowy rynek pracy. W pierwszej połowie lat dwudziestych XX wieku przemysł bułgarski był w stanie zatrudnić co najwyżej 200 tysięcy osób. Imigranci stanowili najniżej opłacaną, niewykwalifikowaną siłę roboczą, co więcej musieli rywalizować o miejsca pracy w fabrykach z miejscowymi robotnikami. Członkowie rady podkreślali, że kryzys na rynku pracy,

${ }^{11}$ N. Vukov, The refugee question in Bulgaria before during and after the First World War, w: Europe on the move: The Great War and its refugees, red. P. Gatrell, L. Zhvanko, s. 265-266.

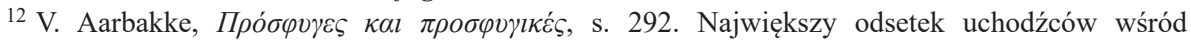
mieszkańców odnotowano w dystrykcie Petricz - w połowie lat dwudziestych wynosił on około $17 \%$. W Sofii uchodźcy stanowili około $11 \%$ całej ludności; J. Lampe, Interwar Sofia versus the Nazi-style Garden City: the struggle over the Muesmann Plan, "Journal of Urban History" 1984, t. 11, nr. 1, s. 45.

${ }^{13} \mathrm{~W}$ oparciu o dane zbierane przez administrację bułgarską, uchodźcy byli klasyfikowani w ramach dwóch kategorii. Pierwszą stanowili robotnicy rolni pochodzący przeważnie z ziem trackich i macedońskich, którzy przed przybyciem do kraju nie posiadali własnych gospodarstw. Do drugiej grupy kwalifikowano imigrantów, którym majątki rolne zostały odebrane drogą konfiskaty bez odszkodowania lub z zapowiedzią uzyskania rekompensaty w bliżej nieokreślonej przyszłości. W tym przypadku najczęściej chodziło o Bułgarów przybywających z Grecji, podlegających akcji wymiany ludności, a także bułgarskich rolników z Dobrudży, którzy w największej liczbie emigrowali w latach 1919-1923; Ethnic minorities, t. 3, s. 324. 
w tym również wysokie bezrobocie, dawały się we znaki nie tylko przybyszom, ale i całemu społeczeństwu, potęgując napięcia społeczne ${ }^{14}$. Masowy napływ imigrantów przyczynił się więc do zaostrzenia problemów, które nurtowały społeczeństwo i gospodarkę od czasu klęski wojennej w 1918 roku. Zdaniem specjalistów, ze względu na brak perspektyw rozwoju przemysłowego w Bułgarii, władze powinny maksymalnie odciążyć ośrodki miejskie, podejmując przemyślaną politykę osadniczą w rejonach wiejskich, Za pierwszorzędny cel uznawano zwiększenie ilości ziemi nadającej się do gospodarowania, w okręgach zasiedlonych przez największą liczbę przybyszów. Za koncepcją rozwinięcia osadnictwa rolniczego przemawiał argument, że wielu imigrantów miało doświadczenie w zakresie prowadzenia gospodarstw rolnych. Ponadto, najwięcej nieużytków, które można było stosunkowo szybko zagospodarować na cele rolnicze znajdowało się wzdłuż granicy z Grecją oraz Rumunią ${ }^{15}$.

Na początku lat dwudziestych w Bułgarii został stworzony specjalny „bank” ziemi, pochodzącej z różnych źródeł, która miała stanowić podstawę dla przeprowadzenia reformy rolnej. Zakładano że beneficjentami reformy staną się także nowo przybyli obywatele, których życie zamierzano związać z gospodarką wiejską. Funduszem zarządzała rządową instytucja o nazwie Dyrekcja do spraw zagospodarowania własności ziemskiej (Дирекцията на трудовата землена собственост). Została ona powołana w połowie 1921 roku i funkcjonowała w ramach ministerstwa rolnictwa. Miała pełnić także rolę ośrodka gromadzącego informacje o przybyszach ${ }^{16}$. Początkowo do funduszu włączono działki pozostawione przez Greków i Turków, emigrujących z Bułgarii. Aby zwiększyć ilość ziemi do rozdania, władze starały się także zajmować te działki, które były nadal użytkowane przez mieszkańców greckojęzycznych i tureckojęzycznych, co niejednokrotnie zmuszało ich do opuszczenia kraju $^{17}$. Popyt na ziemię był jednak nieporównywalnie większy. I tak, w 1926 roku szacowano, że po I wojnie światowej z Bułgarii wyemigrowało blisko 53 tysięcy osób greckiego pochodzenia ${ }^{18}$. Tymczasem tylko w pierwszej połowie 1926 roku deklaracje woli przybycia do ojczyzny wypełniło ponad 60 tysięcy Bułgarów z Grecji, a drugie tyle przebywało już w Bułgarii, wnioskując o działki rolnicze i fundusze na uprawę roli ${ }^{19}$. Aby zwiększyć ilość ziemi, trzeba było sięgnąć po nieużytki, podjąć kosztowne akcje osuszania malarycznych terenów bagiennych, karczować lasy. Władze musiały szukać pieniędzy na tę działalność za granicą i starały się o kredyty.

${ }^{14}$ ILO, op. cit., s. IV.

${ }^{15}$ S. P. Ladas, The exchange of minorities. Bulgaria, Greece and Turkey, New York 1932, s. 592.

${ }^{16}$ Do 1 sierpnia 1924 roku działania w sprawie rejestrowania i lokowania przybyszów należały do kompetencji jednego z departamentów w ramach Ministerstwa Spraw Wewnętrznych.

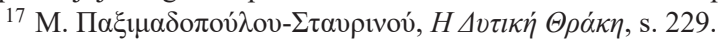

18 T. Dragostinova, Competing priorities, ambiguous loyalties: challenges of socioeconomic adaptation and national inclusion of the interwar Bulgarian refugees, „Nationalities Papers” 2006, t. 34, nr 5, s. 558.

${ }^{19}$ Г. Димитров, Настаняване и оземляване, s. 123. Emigracja muzułmanów z Bułgarii do Republiki Tureckiej sięgnęła w okresie międzywojennym szacunkowo ponad 198500 osób; The Turks of Bulgaria: The history, culture and political fate of a minority, red. K. Karpat, Istanbul 1990, s. 46. 
W 1926 roku Bułgaria otrzymała za pośrednictwem Ligi Narodów pożyczkę międzynarodową na rzecz osadnictwa imigrantów-rolników i inwestycje infrastrukturalne (buł. Бежански заем, 2,4 mln funtów szterlingów z banków europejskich i 4,5 mln dolarów z banków amerykańskich). Celem kolejnego kredytu z 1928 roku było ustabilizowanie finansów państwa, głównie poprzez dokapitalizowanie banku centralnego (buł. Стабилизациионен заем, 5,5 mln funtów szterlingów) ${ }^{20}$. Wydawanie pieniędzy z pożyczki dla uchodźców przebiegało pod kontrolą specjalnie powołanej komisji międzynarodowej, złożonej z przedstawicieli mianowanych przez Ligę Narodów i delegowanych przez rząd bułgarski. Dla kredytodawców komisarze stanowili gwarancję, że fundusze nie zostaną roztrwonione na nieprzemyślane działania ${ }^{21}$.

Decyzja Ligi Narodów, aby wydatkowanie pieniędzy było kontrolowane z zewnątrz, wynikała z oceny ówczesnej sytuacji wewnętrznej w Bułgarii. Przede wszystkim instytucje państwowe, działające na rzecz pomocy uchodźcom funkcjonowały w dużym rozproszeniu. Brakowało centralnego ośrodka, mogącego wyznaczać ogólnopaństwową politykę w tej sprawie. Działania poszczególnych instytucji na poziomie centralnym i lokalnym niejednokrotnie wymykały się spod kontroli władz. Sytuację utrudniała nieprzejrzystość przepisów i chaotyczna organizacja pracy urzędów na różnych szczeblach. Dodajmy, że fiaskiem zakończyły się próby przyjęcia przez władze bułgarskie bardziej perspektywicznego planu działań na rzecz osadnictwa uchodźców. Nieudane próby uporządkowania tej kwestii w polityce państwa podjęto dopiero w 1924 roku, w projekcie ustawy o służbach odpowiedzialnych za losy uchodźców. Jego intencją było stworzenie autonomicznego systemu nadzorowania akcjami osadniczymi, posiadającego wydzielony aparat urzędniczy na czele z Dyrektorem powoływanym przez rząd i komitetem grupującym przedstawicieli wszystkich zainteresowanych instytucji politycznych, finansowych oraz społecznych. Podkreślono konieczność centralizacji zarządzania ziemią dla uchodźców i wprowadzenia odgórnych mechanizmów kontroli w tej kwestii. Plan wydzielenia kwestii uchodźców spośród innych spraw społeczno-gospodarczych w Bułgarii spalił jednak na panewce ze względu na brak wystarczającego wsparcia politycznego w parlamencie i na dworze królewskim. W rezultacie proces przyjmowania imigrantów był prowadzony siłami poszczególnych ministerstw i agend celno-policyjnych ${ }^{22}$.

${ }^{20}$ S. Sierpowski, Liga Narodów w latach 1919-1926, Wrocław 2005, s. 234-237; Д. Вачков, Отношенията на България, s. 90-108.

${ }^{21}$ Strukturaizasady funkcjonowania komisjipowołanej dla wydatkowania pożyczki międzynarodowej dla Bułgarii były wzorowane na rozwiązaniach zastosowanych w 1923 roku w Grecji, która również dostała taką pomoc. W parlamencie bułgarskim i na dworze królewskim zwracano jednak uwagę na odmienną sytuację Bułgarii. Po pierwsze, Bułgarzy napływali do kraju w stosunkowo małych grupach na przestrzeni trzech dziesięcioleci, podczas gdy kulminacja imigracji do Grecji przypadła na lata 19221924. Po drugie, w porównaniu z Grecją, Bułgaria dysponowała mniejszą ilością ziemi, która nadawała się do zasiedlenia, dlatego musiała ponieść większe nakłady finansowe, np. na tworzenie gruntów rolnych; S. P. Ladas, The exchange of minorities, s. 599.

${ }^{22}$ ILO, op. cit., s. 13. 
Kwestia uchodźców w Bułgarii była stałym, choć bynajmniej nie pierwszoplanowym elementem sporów politycznych w państwie. Poszczególne rywalizujące ze sobą środowiska rozmaicie postrzegały miejsce imigrantów w polityce wewnętrznej. Kwestie dotyczące pomocy dla uchodźców były najbardziej bodajże widoczne w polityce Bułgarskiego Ludowego Związku Chłopskiego, który rządził w Bułgarii w latach 1918-1923. Liderowi ludowców A. Stambolijskiemu bardzo zależało na poszerzeniu wiejskiego elektoratu dla swojego ugrupowania, stąd dużo jego deklaracji i planów było poświęconych zagadnieniu rozwinięcia osadnictwa rolniczego w oparciu o uchodźców. W okresie, gdy Bułgaria mierzyła się z bezpośrednimi następstwami klęski wojennej, decyzją rządu wydzielono pierwsze działki pod osadnictwo i opracowano projekty przepisów, mające zapewnić przybywającym standardową opiekę medyczną oraz preferencyjne kredyty. Partia agrarna zamierzała wpisać problem uchodźczy w przygotowywaną przez siebie reformę agrarną, ale nie zdołała jej przeprowadzić pod presją braków finansowych i kryzysu politycznego w państwie. Zamysł podjęcia szeroko zakrojonych i kosztownych społecznie działań na rzecz uchodźców nie został podjęty przez kolejne grupy rządzące ${ }^{23}$. Po odsunięciu ludowców od władzy w następstwie zamachu stanu z 1923 roku, władze ograniczyły się do rozdysponowania ziem państwowych wśród potrzebujących, starając się jednocześnie zwiększyć ilość ziemi uprawnej w kraju. Istotnym celem politycznym dla rządzących było osłabienie frustracji, które narastały w poszczególnych środowiskach imigranckich, pokrywając się z ogólnym niezadowoleniem społecznym w państwie ${ }^{24}$.

Jak wspomniano już wcześniej, o przyjęciu specjalnych procedur administracyjnych wobec uchodźców, polegających na rejestracji i zbieraniu danych o przybyszach, można było mówić tylko w latach 1923-1924, gdy do kraju napłynęła kolejna fala imigrantów z greckiej Tracji, w ramach tzw. nieobowiązkowej wymiany ludności. Zgodnie z przyjętymi wówczas zasadami, ustalonymi w toku rozmów międzyrządowych, przybywający musieli zgłosić się do jednego z trzech punktów przy granicy, znajdujących się w Swilengradzie (w dolinie Maricy), Makaza (Rodopy) lub Sweti Vracz (dolina Strumy, ob. Sandanski). Imigranci przechodzili tam zwykle trzydniową kontrolę graniczną, policyjną i lekarską. W tym czasie znajdowali się oni pod opieką Bułgarskiego Czerwonego Krzyża. Jak obliczano, dzienna przepustowość wspomnianych punktów granicznych oscylowała wokół liczby stu rejestrowanych osób. Tymczasem w trakcie największego nasilenia imigracji, na przełomie 1924 i 1925 roku, na granicy pojawiało się nawet pięciokrotnie więcej przybyszów, co na pewien czas paraliżowało pracę urzędników i służb granicznych ${ }^{25}$. I tak, przed punktem w Swilengradzie thumy oczekujących „kłębiły się” we wrześniu i październiku 1924, a także w okresie od lutego do kwietnia następnego roku. Niemożliwe było zakwate-

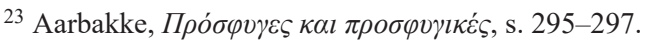

24 T. Dragostinova, Competing priorities, s. 558; Е. Стателова, С. Грънчаров, История на нова България 1878-1944, t. 3, София 2006, s. 426.

25 ILO, op. cit., s. 7. 
rowanie wszystkich oczekujących, bo miejscowe służby były w stanie zapewnić opiekę dla co najwyżej trzystu osób ${ }^{26}$.

Obowiązkiem miejscowych władz było informowanie przybyłych o decyzjach zapadających na szczeblu centralnym, dotyczących rozmieszczenia imigrantów. Władze brały też na siebie obowiązek bezpłatnego dowozu przybyszów do wskazanych miejscowości. Tam lokale mieszkalne były przydzielane najczęściej na użytkowanie tymczasowe, rzadziej na stałe, przez komisje, w których zasiadali przedstawiciele miejscowych władz, delegaci Banku Rolniczego Bułgarii i środowisk uchodźczych. Jeśli uchodźcy byli kierowani na wieś, o ich losach decydowały specjalnie powołane komitety z liderami lokalnych społeczności, miejscowym duchowieństwem prawosławnym, nauczycielami, a także reprezentantami przybyszów. Władze chciały w ten sposób łagodzić napięcia, pojawiające się między ludnością lokalną a napływową, zwykle związane z trudną sytuacją bytową mieszkańców wsi i uchodźców ${ }^{27}$.

Największe problemy dotyczyły niedostatecznej ilości lokali mieszkalnych. Te, które władze przejęły po tureckich i greckich emigrantach nie zaspokoiły olbrzymich potrzeb. Władze musiały kwaterować napływającą ludność w zamieszkanych już lokalach komunalnych i prywatnych, w miastach i na wsi. Akcja zagęszczania dotyczyła zarówno budynków mieszkalnych, jak i gospodarczych, co prowadziło do licznych napięć. Agendy państwowe nie radziły sobie z pomocą materialną dla nowo przybyłych. Choć rządzący obiecywali imigrantom, że do chwili znalezienia pracy władze zaopatrzą ich w żywność, ubrania czy drewno, brakowało dosłownie wszystkiego. Główny ciężar pomocy spoczywał na służbach Czerwonego Krzyża i na zagranicznych organizacjach charytatywnych ${ }^{28}$. Oczywiste jest, że realizacja tych zobowiązań była niemożliwa ze względu na olbrzymią skalę potrzeb. Wielu przybyszów miało bardzo ograniczone możliwości finansowe i szybko się zadłużało. Część latami czekała na wypłatę rekompensat od greckiego rządu za pozostawione nieruchomości ${ }^{29}$.

Kolejna przeszkoda w procesie dostosowywania się uchodźców do nowych warunków życia była związana z nikłą dostępnością kredytów celowych, za które można by wybudować lub wyremontować przejęte mieszkania, czy kupić narzędzia niezbędne do podjęcia działalności zarobkowej. W pierwszej połowie lat dwudziestych władze uruchomiły program pomocy finansowej dla przybyszów poprzez pożyczki celowe. Był on realizowany przez Bank Rolniczy Bułgarii, gdzie państwo było udziałowcem. Dostępne tam kredyty zwykle wynosiły 20 tysięcy, a potem 50 tysięcy lewów, ze spłatą przez 20 lat na 12\%, z możliwością obniżenia do 10\%. Zaangażowanie finansowe państwa w tę pomoc było jednak dalece niezadowalające. I tak, do 1924 roku kredyty z tego źródła otrzymało niepełna 12 tysięcy rodzin, głównie na budo-

\footnotetext{
26 Ibidem, s. 8.

27 S. P. Ladas, The exchange of minorities, s. 592.

28 Българско Дружество Червенъ Кръстъ, Бъжанският въпросъ въ Бългалия, София 1925, s. $22-23$.

${ }^{29}$ ILO, op. cit., s. 10; N. Vukov, op. cit., s. 271.
} 
wę lokali mieszkalnych. W 1925 roku państwo w ogóle przerwało finansowanie tych działań, nie wydzielając w budżecie odpowiednich środków.

Sytuacja społeczna na wsi bułgarskiej była napięta jeszcze przed pojawieniem się masy uchodźców, ze względu na nierozwiązane kwestie, dotyczące reformy rolnej. W Bułgarii widoczny był głód ziemi, który wyrażał się dużą ilością bezrolnych na wsi, utrzymujących się głównie z pracy najemnej. Jak pisano w raporcie MOP z 1926 roku, większość właścicieli drobnych gospodarstw rolnych, aby przetrwać finansowo, musiała najmować się do pracy w innych miejscach, ponieważ nie mogli oni samodzielnie utrzymać rodzin z uprawy niewielkich parceli. Masowo napływający uchodźcy zasilali tę rzeszę najuboższych mieszkańców wsi, to z kolei przekładało się na wzrost presji migracyjnej na miasta. W połowie lat dwudziestych obliczano, że niemal połowa bułgarskich imigrantów zamieszkiwała ośrodki miejskie, tymczasem w zamierzeniach władz odsetek ten powinien stanowić co najwyżej $25 \%$. Zdarzały się przypadki, zwłaszcza w rejonach przygranicznych, że przybysze osiedlali się na nieużytkach za przyzwoleniem władz, budując prowizoryczne schronienia i wegetując na skrawkach samodzielnie zagospodarowanej ziemi uprawnej. Co więcej, jeszcze w latach trzydziestych wielu imigrantów żyło w budynkach gospodarczych, stodołach czy oborach ${ }^{30}$.

W raportach wysłanników Ligi Narodów wielokrotnie podkreślano, że aktywności gospodarczej przybyszów, których w połowie lat dwudziestych XX wieku zdołano osiedlić w środowiskach wiejskich, nie można było uznać za efektywną i znaczącą dla gospodarki całego kraju. Wielu borykało się z problemami adaptacyjnymi oraz - jak to określano - z „fizyczną słabością”, chorobami, niedożywieniem. Według danych organizacji charytatywnych, w połowie lat dwudziestych poziom śmiertelności niemowląt w rejonach Bułgarii południowej, gdzie znajdowała się największa liczba uchodźców, przekraczał 50\% ${ }^{31}$. Jak stwierdzono w raporcie MOP z 1926, wielu przyjezdnych nie dostawało nic ponad zapewnienia władz, że wkrótce dostaną jakieś wsparcie materialne od państwa. Przekazywano informacje o dramatycznej sytuacji sanitarnej w przeludnionych miastach, alarmistycznie pisano o perspektywach życia przybyszów, zwłaszcza tych, którzy nie mogli liczyć na przydział mieszkań w Bułgarii południowej, wschodniej i w samej Sofii. Zwracano także uwagę na dużą popularność wśród poszczególnych środowisk imigrantów ruchów politycznych i paramilitarnych, podważających prawomocność powojennego ładu międzynarodowego. Jak pisał jeden z autorów raportu dla MOP z 1926 roku, wśród uchodźców silne było przekonanie o konieczności wywalczenia przez nich powrotu do rodzinnych stron przy wykorzystaniu metod uznanych za terrorystyczne, naruszających ład wewnętrzny i stosunki międzypaństwowe. Brak perspektyw w pogrążonej w kryzysie Bułgarii sprawiał, że środowiska imigranckie propagowały hasła prowojenne i rewo-

\footnotetext{
${ }^{30}$ ILO, op. cit., s. 9.

31 S. P. Ladas, The exchange of minorities, s. 593.
} 
lucyjne, często stając się narzędziem w rękach ekstremistów, podważających ówczesny porządek międzynarodowy ${ }^{32}$.

Istotnie, kwestia ochrony bezpieczeństwa państwa przed nasilającą się w latach dwudziestych XX wieku aktywnością ruchów ekstremistycznych, zwłaszcza przed komunizmem i skrajnym, szowinistycznym nacjonalizmem, budziła duży niepokój rządzących. Za naturalną ostoję tych środowisk uznawano miasta - tam problemy społeczne, wywołane przez rosnące bezrobocie i niedostateczną ilość mieszkań nawarstwiały się najszybciej. W niepokoju przed rozruchami społecznymi władze gorączkowo poszukiwały miejsc nadających się na osadnictwo rolnicze ${ }^{33}$. W jego rozwoju upatrywano największą szansę na stopniową i najszybszą integrację imigrantów ze strukturami państwa oraz społeczeństwa bułgarskiego. Chodziło o wprzęgnięcie jak największej liczby imigrantów w dotychczasowy system gospodarczy, zdominowany przez niewielkie gospodarstwa rolnicze, za którymi stała grupa społeczna charakteryzująca się tradycyjnie konserwatywnym nastawieniem do spraw społecznych, wspierająca realizację koncepcji narodowego państwa bułgarskiego.

Przybyszów starano się osiedlać w regionach o najbardziej zróżnicowanej charakterystyce narodowościowej, które w większości przylegały do granicy państwowej. Poza tym uchodźcy zwykle zatrzymywali się tam, gdzie było stosunkowo blisko do terenów, które opuścili, w nadziei na możliwość szybkiego powrotu wraz ze zmianą sytuacji politycznej w regionie. Bez wątpienia władze dążyły w Bułgarii południowej i wschodniej do wzmocnienia liczebności żywiołu bułgarskiego kosztem innych grup narodowych i religijnych. $Z$ drugiej strony, nie zdołano doprowadzić do takich zmian jak w Grecji, gdzie osadnictwo imigrantów korespondowało z masowym odpływem mniejszości narodowych i religijnych. W Bułgarii pozostały enklawy, gdzie dominowała ludność turecka lub bułgarscy muzułmanie ${ }^{34}$.

Na początku lat dwudziestych XX wieku część bułgarskiego establishmentu politycznego wiązała z imigrantami nadzieję, na odbudowę i rozwój ekonomiczny regionów najbardziej dotkniętych zniszczeniami wojennymi. Pojawiły się pomysły takiego gospodarowania „zasobami” nowo przybyłej ludności, aby doprowadzić do osiągnięcia swoistej równowagi etnicznej i ekonomicznej w skali całego kraju, zapewniającej bezpieczeństwo granic oraz równomierny rozwój wszystkich jego części. Główne narzędzia tej swoistej ,inżynierii społecznej” nakreślono w rządowych zapowiedziach, że władze będą z rozmysłem zaludniać tereny sukcesywnie opuszczane przez ludność grecką i turecką. Przymierzano się również do tworzenia czegoś w rodzaju bazy wiedzy o umiejętnościach przybyszów, tak by lokować ich odpowiednio do potrzeb gospodarczych $\mathrm{kraju}^{35}$. W połowie lat dwudziestych, $\mathrm{z}$ rzeszy imigrantów starano się kierować do poszczególnych rejonów fachowców w zakresie produkcji wina, przetwórstwa tytoniu, rybołówstwa czy doświadczonych hodow-

\footnotetext{
32 ILO, op. cit., s. 14.

33 Г. Димитров, Настаняване и оземляване, s. 98-99.

34 S. P. Ladas, The exchange of minorities, s. 598.

35 T. Dragostinova, Competing priorities, s. 557.
} 
ców zwierząt. W rzeczywistości, zabrakło jednak konsekwencji w tych działaniach. Wiedza o umiejętnościach zawodowych przybyszów była wyrywkowa, dane zbierano głównie w stosunku do tych, którzy pojawili się w Bułgarii w latach 1924-1925. W rezultacie imigrantów najczęściej lokowano w warunkach, które nie odpowiadały ani ich doświadczeniu, ani przygotowaniu zawodowemu ${ }^{36}$. Wielu przybyszów było też sfrustrowanych istniejącymi ograniczeniami administracyjnymi, które dotyczyły poruszania się po kraju. Chcąc zapanować nad problemem niedostatecznej reprezentacji wykwalifikowanej siły roboczej na zasiedlanych terenach, władze blokowały przenoszenie się osadników nie tylko ze wsi do miast, ale i między regionami. W specjalnych rejestrach umieszczano szewców, murarzy, stolarzy, cieśli i kowali, których przypisywano do konkretnych lokalizacji ${ }^{37}$. Wielu przybyszów nie akceptowało tych arbitralnych decyzji urzędniczych, stąd w całym okresie międzywojennym w Bułgarii istniało zauważalne w skali poszczególnych regionów, ale trudne do statystycznego zobrazowania zjawisko migracji wewnętrznej.

Kwestią, która skomplikowała wewnętrzną sytuację w Bułgarii i jednocześnie ciążyła nad losami wielu bułgarskich imigrantów, był nieustannie utrzymujący się deficyt ziemi, którą państwo było w stanie przekazać osadnikom. Dodajmy, że zagadnienie reformy rolnej w Bułgarii miało dwojakie znaczenie. $\mathrm{Z}$ jednej strony reforma miała doprowadzić do zmniejszenia „głodu ziemi”, który od momentu stworzenia państwa doskwierał zasiedziałej ludności wiejskiej, w większości małorolnej lub bezrolnej. Z drugiej strony trzeba było zapewnić odpowiednią ilość ziemi nowo przybyłym obywatelom. Próby przeprowadzenia zmian w strukturze własności ziemi rolnej podejmowano w parlamencie bułgarskim trzykrotnie, w 1920, 1921 i w 1924 roku. Ostatecznie w ustawie o reformie rolnej, którą przyjęto 1 sierpnia 1924 roku przewidziano zaopatrzenie $\mathrm{w}$ ziemię tych, którzy opierali swoje utrzymanie na pracy na roli, robotników rolnych, bezrolnych i małorolnych chłopów, a także tzw. uchodźców rolnych. W ramach utworzonego wówczas funduszu ziemi, oprócz nieruchomości po emigrantach, uwzględniono parcele znajdujące się pod kontrolą państwa, dwóch banków kontrolowanych przez państwo (Centralnego i Rolniczego), lasy państwowe i komunalne przeznaczone do karczunku oraz obszary bagienne. Ponadto fundusz zasiliła ziemia wyjęta spod kontroli klasztorów, która nie była uprawiana oraz parcele komunalne (gminne), najczęściej wykorzystywane przez lokalnych mieszkańców w celach pasterskich bądź hodowlanych. Zabiegi związane z reformą rolną były podporządkowane zasadzie nieuszczuplania wielkich majątków rolnych, które znajdowały się w rękach prywatnych, a także stanowiły własność rodziny królewskiej. Przez cały czas realizatorzy reformy borykali się z dużym niedoborem ziemi, nadającej się do przekazania na cele rolnicze. Tylko w 1926 roku deficyt ten był szacowany na blisko 80 tysięcy hektarów ${ }^{38}$. Jak oceniano, tylko w przypadku ludności zasiedziałej, liczba rodzin, które czekały na ziemię sięgała blisko 100 tysięcy. Aby zaspokoić

\footnotetext{
${ }^{36}$ Г. Димитров, Настаняване и оземляване, s. 159-160.

${ }^{37}$ Ibidem, s. 77.

${ }^{38}$ ILO, op. cit., s. $31,33$.
} 
najpilniejsze potrzeby ekonomiczne ze strony mieszkańców wsi, państwo bułgarskie musiałoby znaleźć i rozdzielić między obywateli co najmniej 420 tysięcy hektarów ziemi nadającej się do uprawy. Oczywiście myślano o inwestycjach mających prowadzić do zwiększenia areału rolnego kosztem nieużytków państwowych, na to jednak państwo nie miało funduszy ${ }^{39}$.

Realizację reformy opóźniały problemy administracyjne, problematyczny był także odbiór społeczny. Na przeszkodzie stały mnożące się formalności urzędnicze i partykularne interesy osób fizycznych lub instytucji lokalnych, które były zobowiązane do przekazania ziemi do Funduszu Agrarnego. Co więcej, reformę rolną krytykowały także środowiska wiejskie. W ich optyce, komisje gminne, które miały dysponować poszczególnymi działkami, działały opieszale i podejmowały stronnicze decyzje. Zdarzało się, że ziemie przeznaczone do rozdzielenia w danej wsi były przejmowane przez najbogatszych miejscowych gospodarzy, którzy nie chcieli akceptować przybyszów. Rolników frustrowało także, że nie mogli korzystać z gruntów komunalnych, które od lat osiemdziesiątych XIX wieku wykorzystywali do wypasu swoich zwierząt. Utrata dostępu do niemal darmowych pastwisk, które włączono do funduszu agrarnego, oznaczała konieczność opłacania wypasu zwierząt na terenach prywatnych. Znacząco uszczupliło to budżety wiejskich rodzin ${ }^{40}$. W rezultacie opisanych powyżej problemów, w ciągu roku od wejścia w życie reformy rolnej, do 1 grudnia 1925 roku, zdołano przekazać w sumie ponad 27 tysięcy hektarów ziemi uprawnej ponad 8700 rodzin uchodźców. Sytuacji tej nie poprawiły próby stworzenia mechanizmów, gdzie starano się stworzyć mechanizmy odrębnego zaopatrzenia przybyszów w potrzebną ziemię, podejmowane przez parlamenty w latach 1925, 1926 i 1937.

Wobec braku własnych środków na rozwinięcie akcji osadniczej, władze musiały starać się o fundusze zewnętrzne. W 1926 roku rządowi udało się przeprowadzić skuteczną kampanię międzynarodową na rzecz pomocy finansowej dla uchodźców i ich osadnictwa na wsi. W liście do sekretarza generalnego Ligi Narodów strona bułgarska podkreślała konieczność udzielenia pożyczki, aby powstrzymać rosnące wśród imigrantów wpływy komunizmu i skrajnego ruchu nacjonalistycznego. Jak pisał w liście do sekretarza Ligi Narodów bułgarski minister spraw zagranicznych Christo Kalfoff, rozwiązanie „problemu uchodźczego”, powiązanego z fatalną sytuacją bytową przybyszów w Bułgarii, powinna być przedmiotem szczególnego zainteresowania organizacji, bo wykracza poza problematykę stricte wewnętrzną. Poprawa sytuacji uchodźców była według niego warunkiem sine qua non utrzymania i tak wątłej stabilizacji politycznej na Bałkanach ${ }^{41}$.

${ }^{39}$ T. Bouroff, Le reforme agraire en Bulgarie (1921-1924), Paris 1925, s. 99.

40 Г. Димитров, Настаняване и оземляване, s. 38-44

${ }^{41}$ FO, 371/11223, Annual report. Bulgaria 1925, s. 34-35. Jednocześnie rząd bułgarski ogłosił, że będzie wstrzymywał dalszą imigrację Bułgarów z centralnej i wschodniej części Macedonii egejskiej, gdzie wedle wyliczeń strony bułgarskiej mieszkało około 100 tysięcy Słowian (najwięcej w okolicach miasta Florina). O przebiegu rozmów na temat warunków pożyczki na rzecz uchodźców: Д. Вачков, Отноченията на България, 60-73. 
W 1926 roku władze bułgarskie postrzegały pożyczkę jako szansę na poprawę losu wielu uchodźców, znajdujących się w fatalnej sytuacji bytowej. Dwa lata później Bułgaria wnioskowała o kredyt, który miał umożliwić dokończenie działań mających na celu wsparcie procesów społeczno-gospodarczych stabilizujące państwo. W ocenie rządu, w 1926 roku bezwzględnej pomocy finansowej i materialnej wymagało ponad 13 tysięcy rodzin. Dodajmy, że negocjacje w sprawie pożyczki budziły ostry opór ze strony Grecji i Królestwa SHS. Państwa sąsiednie uważały, że fundusze, na które oczekiwał rząd bułgarski, zostaną skierowane na realizację planów wojskowych o charakterze rewizjonistycznym, a nie na realną pomoc osadnikom. Pod wspólnym naciskiem Grecji, Królestwa SHS i Rumunii przyjęto, że akcja osadnicza finansowana $\mathrm{z}$ kredytu nie obejmie całego terytorium Bułgarii i będzie realizowana na terenach oddalonych o co najmniej $50 \mathrm{~km}$ od granicy państwowej ${ }^{42}$. Przyjęta zasada uderzała w interesy większości imigrantów, którzy pierwotnie nie mogli korzystać z pomocy finansowej, ponieważ byli skupieni głównie w rejonach przygranicznych ${ }^{43}$. Ostatecznie drogą konsultacji dyplomatycznych przyjęto, że w wyjątkowych sytuacjach wsparcie w ramach pożyczki dostaną także rodziny znajdujące się w szczególnie złej sytuacji bytowej, niezależnie od miejsca zamieszkania. Decyzja ta umożliwiła skierowanie części środków z pożyczki do rejonów przygranicznych, ale pod warunkiem przeprowadzenia dokładnej kontroli celowości wydatków ${ }^{44}$.

Zgodnie z ustawą o osadnictwie rolniczym, która została przyjęta przez parlament w grudniu 1926 roku, imigrantów zamieszkujących Bułgarię podzielono na trzy grupy ${ }^{45}$. Pierwszą stanowili tzw. ,imigranci ekonomiczni”, którzy zdaniem władz powin-

${ }^{42}$ League of Nations, Scheme for the settlement of Bulgarian refugees. General Description and principal documents, Lausanne 1926, s. 7, 10. Strona bułgarska protestowała przeciwko żądaniom, pojawiającym się na etapie negocjowania warunków pożyczki, aby ze względu na kwestie bezpieczeństwa międzynarodowego przesiedlić sporą część uchodźców w głąb kraju. Władze bułgarskie argumentowały, że ci, którzy osiedlili się blisko granicy, zdążyli się już odnaleźć ekonomicznie i częściowo zasymilować. Ostatecznie przyjęto rozwiązania pośrednie. I tak, uzgodniono, że uchodźcy z Rumunii zostaną przesiedleni do rejonu między miejscowościami Łom-Swisztow, możliwe jak najdalej na południe od linii Dunaju. W kolei w rejonie miejscowości Mastanli we wschodnich Rodopach, osadnictwo bułgarskie zostało dozwolone w odległości od 10 kilometrów od granicy. W przypadku miejscowości Iwajłowgrad i Swilengrad Komisarz LN został zobowiązany do przestudiowania możliwości umieszczenia tamtejszych imigrantów, przeważnie pochodzących z greckiej części Tracji, w innych częściach państwa bułgarskiego, ze względu na ich złą sytuację i nazbyt dużą bliskość do granicy bułgarsko-greckiej. Ostatecznie w marcu 1927 roku podjęto decyzję o częściowym wysiedleniu stamtąd imigrantów, motywując to względami strategicznymi. Oddzielne regulacje poświęcono części gminy Swilengrad, położonej na wschód od rzeki Maricy, gdzie zezwolono na osadnictwo w odległości co najmniej $10 \mathrm{~km}$, ale nie z udziałem imigrantów przybyłych z Grecji; S. P. Ladas, The exchange of minorities, s. 597-598.

43 Tzw. strefy przygraniczne, objęte ,klauzulami ochronnymi” w zakresie osadnictwa, wynosiły w przybliżeniu 57 tysięcy km²; FO, 371/12089, Annual report. Bulgaria 1926, s. 41; S. P. Ladas, The exchange of minorities, s. 596.

${ }^{44}$ O stanowisku politycznym mocarstw wobec bułgarskich starań o pożyczkę w latach 1925-1926: Р. Аврамов, Комуналният капитализъм, София 2007, t. I, s. 384-386.

45 Закон за селскостопанско настаняване на бежанците чрез средствата на заема, отпуснат със съгласието на Общзеството на народите (Закон 1926), 1/14.12.1926 г., „Държавен вестник" 1926, nr 213. 
ni samodzielnie poradzić sobie z problemami bytowymi i w związku z tym nie zostali uznani za beneficjentów pożyczki. Podobnie traktowano osoby zakwalifikowane do drugiej grupy, które przybyły do Bułgarii z - jak to określono - „odpowiednimi” środkami do przeżycia i podjęcia działalności gospodarczej. Trzecią, najliczniejszą grupę tworzyli przybysze, którzy nie mieli możliwości samodzielnego utrzymania siebie i rodzin. Byli to głównie rolnicy, rzemieślnicy wiejscy i rybacy, którzy osiedlili się bądź mieli zostać osiedleni na terenach wiejskich. Pomoc realizowana w ramach pożyczki koncentrowała się właśnie na wsi, zgodnie z założeniem, że należało odciążyć przeludnione miasta. Nowo przybyłych do miast uchodźców władze zachęcały, aby zmienili miejsce zamieszkania, wówczas mogli oni liczyć na odpowiednie wsparcie w postaci ziemi, narzędzi lub kredytów preferencyjnych ${ }^{46}$.

W rezultacie, do skorzystania z pożyczki zakwalifikowano 35928 rodzin (28 032 z terenów wiejskich i 7896 z miast $)^{47}$. W większości beneficjanci pomocy zamieszkiwali okręgi Burgas, Petricz i Płowdiw. Uprawniony otrzymywał ziemię o średnim areale 4 hektarów, ale nie przekraczającym 5 ha. Określono zasady budowy domostw, państwo zapewniało bezpłatny transport materiałów budowlanych. Podjęte zostały prace irygacyjne i melioracyjne, głównie w rejonach czarnomorskim i dunajskim. Za pieniądze z zagranicy prowadzono także karczunek lasów celem poszerzenia gruntów rolnych ${ }^{48}$. Na cele budowlane i inwestycje, głównie komunikacyjne, przeznaczono drugi kredyt międzynarodowy w 1928 roku, w wysokości 5,5 miliona funtów. Zakładano, że planowana infrastruktura mieszkalna powstanie do końca 1929 roku. W kolejnym etapie prac przewidywano rozbudowę infrastruktury socjalnej - budynków szkolnych, świątyń, sieci kanalizacyjnej. Na początku lat trzydziestych szacowano, że blisko 40 tysięcy rodzin otrzymało w różnych formach pomoc sfinansowaną z pożyczek. Była to zarówno ziemia, wyposażenie rolnicze, jak i zwierzęta pociągowe oraz hodowlane ${ }^{49}$.

Podobnie jak w przypadku reformy rolnej, także i realizacja zagranicznej pomocy finansowej dla uchodźców przebiegała wolniej, niż oczekiwali jej autorzy. Zdaniem obserwatorów, władze z trudem pokonywały przeszkody związane ze skomplikowanymi stosunkami własnościowymi, nielogicznymi przepisami i opieszałą biurokracją, zwłaszcza na szczeblu lokalnym. Z drugiej strony zwracano uwagę, że wielu

\footnotetext{
${ }^{46}$ К. Хитилов, Селскостопанското настаняване на бежанциче 1927-1932 2., София 1932 , s. 63 .

${ }^{47} \mathrm{~W}$ miastach pieniądze z pożyczki wydatkowano m.in. na budowę mieszkań dla uchodźców. Na przełomie lat dwudziestych i trzydziestych w Bułgarii upowszechniło się pojęcie domy Charona (Шаронски къщи), od zagranicznego przedstawiciela w Komisji do spraw kredytu zagranicznego, Rene Charona. Parterowe domostwa o określonym standardzie, wznoszono także na wsi. W miastach powstawały one w wybranych lokalizacjach, współtworząc nowe dzielnice, zasiedlone przez uchodźców, np. w Petricz dzielnicę Szaron (Шарон); por. 3. Сотирова, Бежанците от Егейска Македония в Петричка околия след Първата световна война и устройването им (1925-1931 г.), „Международна политика” 2013, nr 1/2, s. 243-244.

48 Г. Димитров, Настаняване и оземляване, s. 176.

${ }^{49}$ FO, 371/14326, Bulgaria. Annual report 1929, s. 9.
} 
uchodźców zyskało wcześniej niespotykaną w Bułgarii szansę poprawy jakości życia w oparciu o gospodarkę rolną, zyskując ziemię i podstawowe wsparcie finansowe lub materialne. Optymistycznym sygnałem było, że wielu beneficjantów pożyczki podjęło w wyznaczonym okresie spłatę zobowiązań, wynikających z otrzymanej pomocy. Było to możliwe dzięki zróżnicowaniu warunków rozliczania się przed bankiem, zależnie od sytuacji materialnej rodzin ${ }^{50}$. Zdaniem zagranicznego komisarza, nadzorującego akcję, wymierne rezultaty pożyczki były plonem pracowitości osadników oraz warunków glebowych i klimatycznych, sprzyjających rozwojowi gospodarki rolnej. W 1928 roku raportowano, że obszar uprawy zboża w Bułgarii wzrósł w ciągu dwóch lat z 23280000 hektarów (1926) do 24496000 hektarów (1928). W 1929 roku ilość ziemi uprawnej w Bułgarii po raz pierwszy przewyższyła odnotowaną w 1912 roku, gdy państwo to nie miało jeszcze okrojonego terytorium wskutek klęsk wojennych ${ }^{51}$. Niestety w kolejnych latach ten pozytywny trend został zahamowany, w dużej mierze w następstwie obniżenia cen zboża z powodu wielkiego kryzysu ekonomicznego.

W opinii komisji mieszanej, nadzorującej wydawanie pożyczki, pomoc trafiała do najbardziej potrzebujących, bo wydatki były kontrolowane przez gremium międzynarodowe. Administracja państwa bułgarskiego nie miała ostatecznego wpływu na lokowanie poszczególnych środków, choć oczywiście uczestniczyła w realizacji wyznaczonych działań. Na szczeblu centralnym odbywało się to poprzez specjalny organ o nazwie Główna dyrekcja do spraw osadnictwa uchodźców (Главна дирекция по настаняване на бежанциите, 1927-1931). W szczególności doceniono humanitarny walor pożyczki i to, że przyczyniła się ona do ograniczenia zjawiska przechodzenia uchodźców do oddziałów komickich, aktywnych wzdłuż południowej i zachodniej granicy Bułgarii. Zdaniem ambasady brytyjskiej, potencjalni członkowie band zyskiwali szansę stania się pełnoprawnymi rolnikami, co więcej otrzymywali konieczne wsparcie dla utrzymania i rozwijania swojej działalności gospodarczej. Pożyczka pozytywnie wpłynęła także na gospodarkę wewnętrzną państwa na przełomie lat dwudziestych i trzydziestych. Firmy, które realizowały inwestycje budowlane i komunikacyjne, finansowane z kredytów zagranicznych, potrzebowały niewykwalifikowanej siły roboczej, kupowały surowce oraz żywność na miejscowym rynku, przyczyniając się do rozruszania koniunktury w sferze handlu i usług ${ }^{52}$. Za największy sukces o wy-

${ }^{50} \mathrm{Na}$ początku lat trzydziestych kluczową kwestią polityczną i ekonomiczną były płatności od uchodźców, związane z udzieloną im pomocą finansową. Wielu imigrantów z Grecji spieniężyło na ten cel obligacje państwowe, otrzymane na podstawie grecko-bułgarskiej umowy o nieobowiązkowej migracji. Gorzej wyglądała sprawa uregulowania zadośćuczynienia finansowego, którego Grecja odmawiała stronie bułgarskiej, choć jego warunki uzgodniono jeszcze w 1927 roku. Z kolei od imigrantów z Tracji wschodniej oczekiwano, że spłacą połowę zobowiązań wobec państwa, ponieważ nie dostali żadnego zadośćuczynienia za porzucone nieruchomości od Turcji; S. Ladas, op. cit., s. 614.

${ }^{51}$ FO, 371/14326, Bulgaria. Annual report 1929, s. 11; Д. Вачков, Отношенията на България, s. 80 .

52 Do prac finansowanych z kredytów międzynarodowych wykorzystywano m.in. obowiązkowe korpusy pracy (buł. трудоваии), stworzone w 1920 roku, które stanowiły zastępczą formę dla służby wojskowej w Bułgarii, objętej ograniczeniami w zakresie liczebności sił zbrojnych; FO, 371/14326, Bulgaria. Annual report 1929, s. 9-10. 
miarze cywilizacyjnym uznano jednak zmiany, jakie nastąpiły w tym okresie w pasie wybrzeża czarnomorskiego. Zdaniem obserwatorów międzynarodowych, region, który od czasu emigracji Greków znajdował się w zapaści ekonomicznej, na początku lat trzydziestych XX wieku przekształcił się w dynamiczny ośrodek produkcji rolnej i rybołówstwa. Był to rezultat budowy nowych połączeń drogowych i osuszania terenów podmokłych, które wcześniej separowały wybrzeże od wnętrza terytorium państwa, tworząc rozległe pasy ziemi niczyjej.

W ramach komisji mieszanej, którą Liga Narodów powołała do kontroli wydatkowania pożyczki ustalono, że w każdej wsi objętej akcją osadniczą powinno powstać około trzech, czterech gospodarstw prowadzonych przez rodziny imigrantów. Wymieszanie ludności miejscowej z napływową uznano za najlepszy sposób asymilacji przybyszów z miejscowymi środowiskami. Proces ten był w wielu miejscach utrudniony ze względu na konflikty, występujące między napływającymi imigrantami a miejscową ludnością. I tak, odnotowywano przypadki, gdy wspólnoty mieszkańców blokowały przekazywanie ziem po Grekach i Turkach imigrantom, uważając, że powinny one służyć miejscowym i zasilić grunty wspólnie użytkowane przez poszczególne wspólnoty wiejskie. Imigranci niejednokrotnie skarżyli się, że do ich rąk trafiała ziemia najgorszej jakości, podczas gdy urodzajniejsze parcele były przejmowane przez najbardziej wpływowe, zasiedziałe rodziny ${ }^{53}$. Zdaniem liderów środowisk uchodźczych, we władzach lokalnych istniały nieformalne sojusze między ,,autochtonami" a urzędnikami państwowymi, którzy celowo marginalizowali nowo przybyłych osadników. Na niewiele zdały się żądania części środowisk imigranckich, aby wzmocnić pozycję ich przedstawicieli w organach władzy lokalnej, odpowiadających za pomoc imigrantom ${ }^{54}$. Obserwowane animozje, związane $\mathrm{z}$ osadnictwem bułgarskich imigrantów, wynikały z ogólniejszej atmosfery politycznej w państwie. Ogólnie rzecz ujmując, przybysze byli traktowani przez pozostałych obywateli z pewnym dystansem. Uznawano ich za ludność trudną do kontrolowania, podatną na skrajne ideologie polityczne. Nierzadko wyrażano przekonanie, że większość imigrantów nie myślała o dłuższym pobycie w Bułgarii i nie była zainteresowana całkowitą asymilacją ze społeczeństwem, ponieważ czekali oni na możliwość powrotu do swoich rodzinnych stron. Istotnie, chęć powrotu, artykułowana przez wiele stowarzyszeń imigranckich, znajdowała upust w aktywności politycznej i wspieraniu działań grup paramilitarnych o charakterze rewizjonistycznym. W czasie II wojny światowej, imigranci stanowili także trzon kadry wojskowej i administracyjnej państwa bułgarskiego, które przejęło kontrolę nad częścią terytorium greckiego i jugosłowiańskiego. Byli i tacy, którzy w 1941 roku, po pokonaniu przez państwa Osi Jugosławii i Grecji, powracali do rodzinnych stron, aby ponownie je opuścić w 1944 i 1945 roku ${ }^{55}$.

53 Г. Димитров, Настаняване и оземляване, s. 171.

54 T. Dragostinova, Competing priorities, s. 565.

55 Национално-освободителното движение на македонските и тракийските българи 18781944, София 2003, t. 4, s. 366. 
Wspólnota doświadczeń, pielęgnowana w ramach poszczególnych środowisk odgrywała ważną rolę w oddolnym organizowaniu się imigrantów, którzy jednak nie byli w stanie stworzyć jednolitej reprezentacji politycznej w państwie. Wielu przybyszów, walcząc o przetrwanie, deklarowało brak zaufania dla oficjalnej polityki i starało się pozostać poza oficjalnym systemem odniesień społeczno-politycznych. Organizowali się oni w środowiska, pielęgnujące etos „raju utraconego”, działające na rzecz utrzymania kontaktów między przybyszami z tej samej miejscowości bądź regionu. Stowarzyszenia imigranckie, które najliczniej działały na południu i wschodzie kraju, nie aspirowały jednak do stworzenia formacji ogólnopaństwowej, mogącej reprezentować interesy przybyszów wobec władz państwowych ${ }^{56}$. Wielu liderów tych środowisk dało się natomiast poznać jako rzecznicy retoryki o charakterze nacjonalistycznym i rewizjonistycznym, rozwijanej przez poszczególne środowiska polityczne w państwie. Sprzeciw wobec realiów ładu wersalskiego na Bałkanach dominował w ich wystąpieniach publicznych, wtapiając się w dyskurs ogólnonarodowy. W ślad za greckimi raportami dyplomatycznymi, w zagranicznych opisach spraw bułgarskich na określenie tych osób używano terminu „zawodowi Bułgarzy”. Określenie to odnosiło się do przybyszów, którzy nie czuli pełnej łączności z państwem bułgarskim w granicach nakreślonych postanowieniami traktatu z Neuilly. Działali raczej na rzecz ziszczenia się idei zjednoczenia ziem narodowo i historycznie bułgarskich w państwie nakreślonym w niezrealizowanej umowie pokojowej z San Stefano (1877). Choć wizja tzw. Sanstefańskiej Bułgarii poniosła porażkę podczas I wojny światowej, to jednak dla wielu Bułgarów pozostawała ona perspektywicznym projektem politycznym ${ }^{57}$. W tym ujęciu, przeprowadzenie zjednoczenia narodowego Bułgarów oznaczałoby powrót uchodźców do rodzinnych stron. Rzecznicy rewizjonizmu bułgarskiego uczestniczyli w polityce wewnętrznej i wpływali na aktywność zagraniczną państwa, ale nie reprezentowali interesów środowisk imigranckich jako całości ${ }^{58}$. Wpływy poszczególnych liderów były wzmacniane poprzez ich aktywność $\mathrm{w}$ instytucjach administracyjnych. Na niwie lokalnej często decydowali oni chociażby o dystrybucji pomocy kierowanej dla mieszkańców poszczególnych wspólnot ${ }^{59}$.

Podkreślić należy, że większość imigrantów w Bułgarii dążyła jednak do stabilizacji w warunkach nakreślonych przez ówczesną rzeczywistość społeczno-polityczną. Starali się oni wieść spokojne życie, nie angażowali się w bieżącą politykę. $\mathrm{Z}$ drugiej strony, jak wynika z obserwacji międzywojennego bułgarskiego życia społeczno-politycznego, wśród środowisk imigranckich pokutowało jednak przekonanie

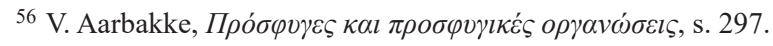

${ }^{57}$ Więcej o mitologemie/ideologemie Sanstefańskiej Bułgarii: J. Sujecka, The image of Macedonia and the categories rod - narod - natsiya in literature from Macedonia in the $19^{\text {th }}$ and first half of the $20^{\text {th }}$ century, w: Macedonia: Land, Region, Borderland, red. J. Sujecka, Warsaw 2013, s. 137-231; idem, Българското национано пространство, w: Концепти на българската култура, Университет в Шумен, Шумен 2010, s. 263-274.

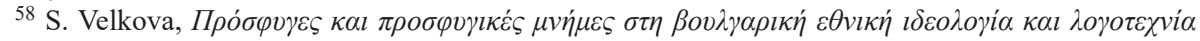

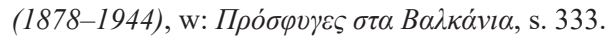

${ }^{59}$ Национално-освободителното движение, s. 259.
} 
o ich niedopasowaniu do struktur państwa. W korespondencji przybyszów daje o sobie znać poczucie rozdarcia między tożsamością narodową a państwową. Emigrowali oni do Bułgarii z racji tego, że władze sąsiednich państw uważały ich za niepożądaną mniejszość narodową, podczas gdy oni nie zawsze w pełni identyfikowali się z bułgarskością. Po przybyciu do kraju, ich tożsamość, oparta na kryterium terytorialnym (,mała ojczyzna”) traciła na wyrazistości, wzrastał nacisk ze strony propagandy narodowej, rozwijanej przez państwo. Jednocześnie po przekroczeniu granicy uchodźcy nierzadko napotykali opór, czasem wręcz wrogość ze strony miejscowych Bułgarów. Sytuacja braku stabilizacji i perspektyw na bezpieczne życie sprzyjała tworzeniu się szczególnego typu świadomości wśród przybyszów. Choć żyli oni w macierzystym narodowo kraju, nie chcieli porzucić myśli o powrocie do stron rodzinnych, ponieważ często uznawali je za główne źródło swojej odrębności ${ }^{60}$.

Dramatyczna sytuacja bytowa przybyszów i nierzadko skomplikowane relacje z miejscową ludnością oraz administracją prowadziły do dystansowania poszczególnych grup uchodźczych od reszty społeczeństwa. Z drugiej strony, masowość zjawiska imigracji sprawiła, że w bułgarskiej polityce wewnętrznej i zagranicznej na znaczeniu zyskała kwestia rewizji granic, traktowana już nie tylko jako sposób ziszczenia idei Bułgarii jako mocarstwa regionalnego. W optyce rzeczników tego nurtu, realizacja planów rewizjonistycznych stanowiła wyraz wsparcia dla oczekiwań wielu imigrantów, którzy nie mogli lub nie chcieli do końca pogodzić ze swoim życiem w Bułgarii. Wobec braku niewystarczającego potencjału ekonomicznego państwa, elity polityczne ulegały przekonaniu, że najskuteczniejszym, najszybciej działającym spoiwem dla społeczeństwa bułgarskiego będą działania mające na celu negację ówczesnych rozwiązań geopolitycznych. Przekonanie to częściowo należy tłumaczyć koniecznością przekonania rzeszy przybyszów do tego, że państwo bułgarskie podzielało zapatrywania na odwracalność losu uchodźcy.

Bez wątpienia, napływ imigrantów do Bułgarii, obserwowany w dwóch pierwszych dziesięcioleciach XX wieku, przyczynił się do ukształtowania współczesnego oblicza społeczeństwa bułgarskiego. Przede wszystkim przybysze odmienili południowe i wschodnie regiony państwa. Za sukces władze uznały działania osadnicze, prowadzone w regionach Burgas, Chaskowo i Petricz, gdzie znacząco ograniczono liczbę ludności tureckiej i greckiej. Przy znaczącym udziale imigrantów władze wzmocniły tradycyjne struktury gospodarcze na bułgarskiej wsi, charakteryzujące się przewagą drobnych gospodarstw rolniczych. Rezultatem było także liczebne i ekonomiczne wzmocnienie chłopstwa jako grupy społecznej, wpływającej stabilizująco na kwestie społeczne i kulturowe w państwie. Napływ fali uchodźców do Bułgarii nie przełożył się jednak na spektakularny rozwój ekonomiczny kraju. Jego gospodarka była zdominowana przez rozdrobnione rolnictwo i nadal niedoinwestowana. $\mathrm{Z}$ drugiej strony, skala przedsięwzięć infrastrukturalnych, które podjęto w związku z pożyczkami międzynarodowymi, umożliwiła częściową pacyfikację zagrożeń społecznych i ekonomicznych, związanych z tzw. problemem uchodźczym w państwie

${ }^{60}$ T. Dragostinova, Competing priorities, s. 565-566. 
bułgarskim. Asymilacja nowo przybyłej ludności postępowała także dzięki temu, że zdecydowana większość uchodźców legitymowała się tym samym pochodzeniem narodowym co ludność miejscowa. $Z$ ekonomicznego punktu widzenia, przybysze zintegrowali się z istniejącymi strukturami państwa i społeczeństwa. $Z$ drugiej strony funkcjonowali jednak, zachowując swoją odrębność, zależnie od miejsca pochodzenia czy doświadczeń migracyjnych. Tak więc, zróżnicowana pod względem pochodzenia i tradycji rzesza uchodźców w Bułgarii tworzyła swoisty, trudny do jednoznacznego zakwalifikowania fenomen w życiu społeczeństwa oraz państwa bułgarskiego. „Kwestia uchodźcza” wywierała ważki wpływ na kształtowanie się głównych nurtów polityki bułgarskiej, choć jednocześnie miała rolę subsydiarną wobec pilniejszych interesów narodowych.

\section{BIBLIOGRAFIA}

\section{Źródla}

National Archives, Foreign Office Archive, London

371/11223, 371/12089, 371/12864, 371/14326,

International Labour Office, Refugees and labour conditions in Bulgaria, „Studies and reports” 1926, ser. $\mathrm{B}, \mathrm{nr} 15$.

League of Nations, Scheme for the settlement of Bulgarian refugees. General Description and principal documents, Lausanne 1926.

Société des Nations/ League of Nations, ,Journal Officiel/Official journal” 1921, t. 2, nr 3.

***

Българско Дружество Червенъ Кръстъ, Бъжанският въпросъ въ Бългалия, София 1925.

„Дьржавен вестник” 1924, nr 213.

Царство България. Главна Дирекция на Статиската, Преброявание на населението. 1934, София 1935.

\section{Opracowania}

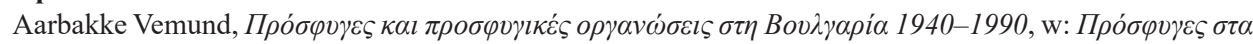

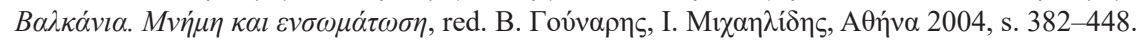

Bouroff T., Le reforme agraire en Bulgarie (1921-1924), Paris 1925.

Dragostinova Theodora, Competing priorities, ambiguous loyalties: challenges of socioeconomic adaptation and national inclusion of the interwar Bulgarian refugees, „Nationalities Papers”, t. 34, nr 5, 2006, s. 549-574.

Ethnic minorities in the Balkan states 1860-1971, red. B. Destani, London 2003, t. 3.

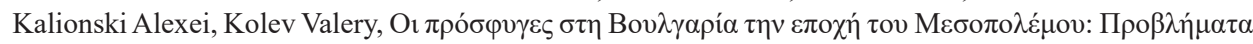

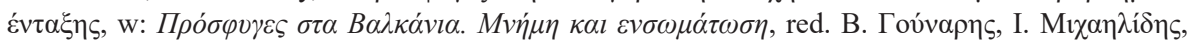
A $\theta$ íva 2004, s. 287-328.

Ladas Stephen P., The exchange of minorities. Bulgaria, Greece and Turkey, New York 1932.

Lampe John, Interwar Sofia versus the Nazi-style Garden City: the struggle over the Muesmann Plan, "Journal of Urban History" 1984, t. 11, nr. 1, s. 39-62.

Mintchev Vesselin, External migration and external migration policies in Bulgaria, „South-East Europe Review for Labour and Social Affairs" 1999, t. II, nr 3.

Sierpowski Stanisław, Liga Narodów w latach 1919-1926, Wrocław 2005.

The Turks of Bulgaria: The history, culture and political fate of a minority, red. K. Kemal, Istanbul 1990. 
Sujecka Jolanta, The image of Macedonia and the categories rod - narod - natsiya in literature from Macedonia in the $19^{\text {th }}$ and first half of the $20^{\text {th }}$ century, w: Macedonia: Land, Region, Borderland, red. J. Sujecka, Warsaw 2013, s. 137-231.

Sujecka Jolanta, Българското начионано пространство, w: Концепти на българската култура, Шумен 2010, s. 263-274.

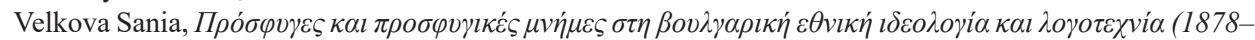

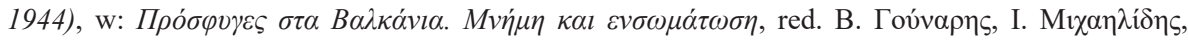
A $\theta$ пंva 2004, s. 329-382.

Vukov Nikolai, The refugee question in Bulgaria before during and after the First World War, w: Europe on the move: The Great War and its refugees, red. G. Peter, Z. Liubov, s. 260-283.

$* * *$

Аврамов Румен, Комуналният капитализъм, София 2007, t. 1, s. 384-386.

Вачков Даниел, Отношенията на България с международните финансови среди, 1926-1931, w: История на външния държавен дълг на България 1878-1990 г., red. М. Иванов, Ц. Тодорова, Д. Вачков, София 2009, t. 2, s. 60-73.

Димитров Георги, Илюзии и действителност. Спорове за права и имоти на българите от Егейска Македония и Западна Тракия 1919-1931 г., Благоевград, 1996.

Димитров Георги, Малцинствено-бежанският въпрос в българо-гръиките отномения (19191939), Благоевград 1982.

Димитров Георги, Настаняване и оземляване на българските бежанци: 1919-1939, Благоевград 1985.

Национално-освободителното движение на македонските и тракийските българи 1878-1944, София 2003, t. 4.

Сотирова Златка, Бежанщите от Егейска Македония в Петричка околия след Първата световна война и устройването им (1925-1931 г.), „Международна политика” 2013, nr 1/2, s. 233-247.

Стателова Елена, Грънчаров Стойчо, История на нова България 1878-1944, София 2006, t. 3.

Хитилов К., Селскостопанското настаняване на бежанците 1927-1932 г., София 1932.

***

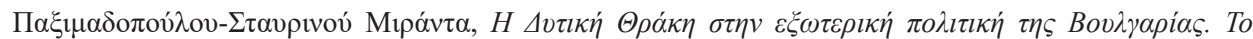

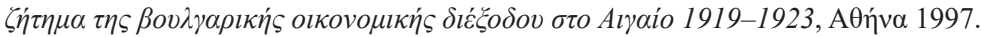

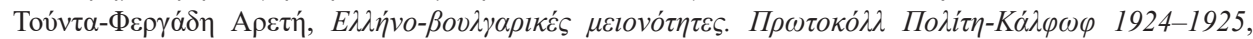

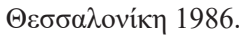


